\title{
KONSEP SENI ISLAM SAYYID HUSEIN NASR
}

\author{
Khudori Soleh \\ Fakultas Psikologi UIN Maulana Malik Ibrahim Malang. Jalan Gajayana 50 Malang 65114. \\ Telp. 0341-558916. e-mail: khudori_uin@yahoo.com
}

\section{Abstract}

Sayyid Husein Nasr divided art into three parts: pure art, traditional art and religious art. Islamic art included on pure art, relates to the principle of cosmos unity and principle of individual life unity and society. Because of that, according to Nasr, thinking about Islamic art is not based on material and social political experience that scope on inner reality of al Quran. In other hand, Islamic art also based on wisdom or knowledge that inspired of spiritual values, therefore Islamic art can be made as a result of khazain al ghaib. Because of that, Islamic art always reflected on religious values and explained of spiritual qualities. Actually, there are four functions which carry out by Islamic art. (1) Aims a blessed as cause of spiritual relation with Islamic spiritual dimension; (2) Remembering presence of the God in everywhere peoples are; (3) As criteria to evaluate social movement, cultural or politic that really Islamic or not; (4) to determined step of intellectual relation and religious of society.

Key words: art and spiritual

\section{Pendahuluan}

Jika mengikuti Iqbal, sebuah karya seni minimal harus mengandung dua hal. Pertama, seni harus merupakan karya kreatif sang seniman, sehingga 
karya seni merupakan buatan manusia dalam citra ciptaan Tuhan. Ini sesuai dengan pandangan Iqbal tentang hidup dan kehidupan. Menurutnya, hakikat hidup adalah kreativitas karena dengan sifat-sifat itulah Tuhan sebagai sang Maha Hidup mencipta dan menggerakan semesta (Syarif, 1993: 121). Kedua, bahwa kreativitas tersebut bukan sekadar membuat sesuatu tetapi harus benar-benar menguraikan jati diri sang seniman, sehingga karyanya bukan merupakan tiruan dari yang lain (imitasi), dari karya seni sebelumnya maupun dari alam semesta. Bagi Iqbal, manusia adalah pencipta bukan peniru, dan pemburu bukan mangsa, sehingga hasil karya seninya harus menciptakan 'apa yang seharusnya' dan 'apa yang belum ada', bukan sekadar menggambarkan 'apa yang ada' (Azzam, 1985: 141). Berdasarkan hal itu, dalam kajian filsafat, gagasan seni Iqbal ini biasanya disebut sebagai estetika vitalisme, yakni bahwa seni dan keindahan merupakan ekspresi ego dalam kerangka prinsip-prinsip universal dari suatu dorongan hidup yang berdenyut dibalik kehidupan sehingga harus juga memberikan kehidupan baru atau memberikan semangat hidup bagi lingkungannya, atau bahkan mampu memberikan "hal baru" bagi kehidupan (Mudhaffir, 1988: 100).

Konsep seni Sayyid Husein Nasr ternyata tidak jauh berbeda dengan konsep seni ekspresional Iqbal tersebut. Menurutnya, seni Islam setidaknya harus mengandung tiga hal penting. Pertama, mencerminkan nilai-nilai religius ajaran Islam, sehingga tidak ada yang disebut seni sekuler. Tidak ada dikotomi antara religius dan sekuler di dalam Islam. Apa yang disebut sebagai kekuatan atau unsur sekuler di dalam masyarakat Islam selalu memiliki pengertian religius, seperti halnya hukum Ilahi yang secara spesifik memiliki unsur-unsur religius. Kedua, menjelaskan kualitas-kualitas spiritual Islam yang bersifat santun akibat pengaruh nilai-nilai sufisme. Ketiga, terdapat hubungan yang halus dan saling melengkapi antara masjid dan istana dalam hal perlindungan, penggunaan, dan fungsi berbagai seni. Karena itu, seni Islam tidak hanya berkaitan dengan bahan-bahan material yang digunakan, tetapi yang terpenting adalah adanya unsur kesadaran religius kolektif yang menjiwai bahan-bahan material tersebut (Nasr, 1993: 22-23).

Meski demikian, tampak jelas perbedaan "kontens" antara konsep seni Husein Nasr dengan Iqbal; yang pertama mendasarkan diri pada nilai-nilai dan semangat spiritual sedang yang kedua mendasarkan pada kemampuan dan potensi diri manusia. Tulisan ini akan menjelaskan lebih lanjut tentang pokok-pokok pemikiran seni Islam Husein Nasr, mulai klasifikasi seni religius secara umum di mana seni Islam masuk di dalamnya, konsep tentang seni Islam sendiri dan fungsi-fungsi yang diembannya. 


\section{Biografi}

Sayyid Husein Nasr lahir di Teheran, Iran, 7 April 1933, dari keluarga terpelajar (Smith, 1995: 230). Pendidikan awalnya dijalani di Teheran, kemudian di Qum dalam bidang al Quran, syair-syair Persia klasik dan sufisme (Dahlan, 1996: 80). Ia kemudian melanjutkan sarjana muda di Massachusetts Institute of Technologi (MIT) AS, dalam bidang fisika dan matematika teoritis, tahun 1954 (Smith, 1995: 230), tingkat Master dalam bidang geologi dan geofisika dari Harvard. Namun, pada jenjang berikutnya, Nasr lebih tertarik pada filsafat, sehingga meraih $\mathrm{PhD}$ dari Harvard, tahun 1958, dalam bidang sejarah ilmu pengetahuan dan filsafat dengan desertasi berjudul An Introduction to Islamic Cosmological Doctrine di bawah promotor HAR. Gibb (Smith, 1995: 230).

Tahun 1958 Nasr pulang ke Iran. Di sini ia mendalami Filsafat Timur dan Filsafat Tradisional dengan banyak berdiskusi bersama para tokoh agama Iran, seperti Thabathabai, Abu Hasan al Qazwini, dan Kazin Asar (Dahlan, 1996: 80). Dalam kegiatan akademik, Nasr mengajar di Universitas Teheran, menjadi dekan Fakultas Sastra pada lembaga yang sama tahun 1968-1972, menjadi direktur Imperial Iranian Academy of Philosophy, tahun 1975-1979. Nasr dinilai berhasil dalam tugas ini sehingga mendapat gelar kebangsawanan oleh Syah (Smith, 1995: 230).

Kredibilitas Nasr sebagai intelektual dan akademisi dapat dilihat pada seringnya diundang sebagai pembicara atau pengajar di berbagai Perguruan Tinggi ternama, antara lain, di Harvard, USA, tahun 1962-1965; di American University of Beirut tahun 1964-1965; menjadi direktur lembaga Aga Khan untuk kajian keislaman (Aga Khan Chair of Islamic Studies) (Nasr, 1986: 7); pembicara pada Pakistan Philosophical Congress di Pakistan tahun 1964 (Qodir, 1997: 155); memberi kuliah di Universitas Chicago, tahun 1966 (Nasr, 1968: 13); di Gifford Lectures, tahun 1981, lembaga yang didirikan oleh Edinburg University pada tahun 1889. Nasr juga pernah datang ke Indonesia pada bulan Juni 1993 atas undangan Yayasan Wakaf Paramadina bekerja sama dengan penerbit Mizan. Di sini ia memberi tiga ceramah dengan topik berbeda, yaitu (1) 'Seni Islam' sekaligus peluncuran buku Spiritualitas dan Seni Islam (Bandung, Mizan, 1993), (2) 'Spiritualitas, Krisis Dunia Modern dan Agama Masa Depan', dan (3) 'Filsafat Perenial'.

Saat terjadi revolusi Iran yang digerakkan Khumaini pada tahun 1979, Nasr terpaksa meninggalkan tanah airnya menuju Amerika karena dianggap pro-Syah (Smith, 1995: 230). Meski demikian, kredibilitasnya sebagai ilmuan tidak berkurang, sehingga ia diangkat menjadi guru besar Studi Islam di George 
Washington University dan guru besar Studi Islam dan agama-agama di Temple University, Philadelphia.

Nasr banyak menghasilkan karya tulis, antara lain, An Introduction to Islamic Cosmological Doctrines (Disertasi, Thames and Hudson Ltd, 1978), Ideals and Realities of Islam (London, George Allen \& Unwim Ltd, 1966), Islamic Studies, Essays on Law and Society, The Sciences, and Philosophy and Sufism (Beirut, Librairie Du Liban Press, 1967), The Encounter of Man and Nature, the Spiritual Crisis of Man and Nature (London, George Allen \& Unwind Ltd, 1968), Science and Civilization in Islam (Harvard, Harvard University Press, 1968), Sufi Essays (London, George Allen \& Unwind Ltd, 1972), Islam and The Plight of Modern Man (London, Longman press, 1975), dan Knowledge and The Sacred (Edinburg, Edinburg University Press, 1981). Selain itu, Nasr aktif menulis artikel untuk jurnal-jurnal ilmiah di berbagai negara, antara lain Journal Milla wa Milla (Melbourne, Australia), Journal Iran (London, Inggris), Studies in Comparative Religion (London, Inggris), Religious Studies (Cambridge, Inggris), The Islamic Quartelly (London, Inggris), Hamdard Islamicus, dan World Spirituality (Nasr, 1972: 21).

\section{Klasifikasi Seni}

Husein Nasr, dalam soal hubungan antara seni dan agama, membagi seni ke dalam tiga bagian. Pertama, seni suci, yakni seni yang berhubungan langsung dengan praktik-praktik utama agama dan kehidupan spiritual. Lawan dari seni suci adalah seni profan. Kedua, seni tradisional, yaitu seni yang menggambarkan prinsip-prinsip agama dan spiritual, tetapi dengan cara tidak langsung. Lawannya adalah seni anti-tradisional. Perbedaan antara seni suci dan seni tradisional ini bisa dilihat pada contoh sebuah pedang. Pedang yang dibuat abad pertengahan, baik Islam maupun Kristen, tidak pernah digunakan secara langsung dalam acara ritual keagamaan meskipun merefleksikan prinsip dan ajaran Islam atau Kristen. Karena itu, ia masuk kategori seni tradisional. Hal ini berbeda dengan pedang Shinto di Kuil I Se di Jepang. Pedang Shinto dikaitkan langsung dengan ajaran agama tersebut dan merupakan objek ritual yang bermakna tinggi dalam agama Shinto, sehingga dimasukkan sebagai seni suci. Ketiga, seni religius, seni yang subjek atau fungsinya bertema keagamaan, namun bentuk dan cara pelaksanaannya tidak bersifat tradisional. Masuk dalam kategori ini adalah lukisan-lukisan religius dan arsitektur Barat sejak Renaissance, serta beberapa lukisan religius di dunia Timur selama se abad atau dua abad lalu di bawah pengaruh seni Eropa (Nasr, 1993: 15). 
Selanjutnya, untuk memahami lebih lanjut tentang seni suci, seseorang mesti memahami pandangan masyarakat tentang realitas, kosmik maupun metakosmik (Nasr, 1993: 15). Dalam pandangan filsafat Islam, realitas adalah multi struktur, yakni mempunyai berbagai tingkat eksistensi. Realitas berasal dari Yang Esa dan terdiri atas berbagai tingkat yang sesuai dengan kosmologi Islam, dapat diringkas sebagai alam malaikat, alam psikis dan alam material (fisik). Manusia hidup di dalam alam material, namun sekaligus dikelilingi oleh seluruh tingkat eksistensi yang lebih tinggi. Yang suci menandai suatu pemunculan dunia yang lebih tinggi dalam hal eksistensi psikis dan material, keabadian dunia temporal. Semua yang datang dari dunia spiritual adalah suci karena berperan sebagai sarana untuk kembalinya manusia menuju dunia spiritual. Walaupun demikian, kemungkinan untuk kembali ke dunia yang lebih tinggi itu tidak dapat dipisahkan dari realitas penurunan dari yang atas, karena pada dasarnya hanya yang datang dari dunia spiritual itulah yang dapat bertindak sebagai sarana untuk kembali ke dunia yang lebih tinggi. Karena itu, yang suci menandakan adanya 'keajaiban' nilai spiritual dalam dunia material. Ia merupakan gema dari surga untuk mengingatkan manusia di bumi akan tempat asalnya, surga.

Berdasarkan hal tersebut, seni suci berarti mempunyai atau mengikuti prinsip-prinsip tertentu yang berkaitan dengan nilai-nilai Ilahiyah atau dimensi spiritual. Pertama, mengikuti prinsip kesatuan kosmos dan apa yang ada dibalik semesta dengan kesatuan prinsip Ketuhanan (Nasr, 1993: 72). Kosmologi Islam didasarkan pada penekanan Tuhan sebagai satu-satunya sumber segala sesuatu, yang mengatur dan menghubungkan eksistensi-eksistensi yang ada di bawahnya; menghubungkan dunia material dengan dunia metafisik, dunia metafisik dengan alam malaikat, alam malaikat dengan alam malaikat muqarrabin, alam malaikat muqarrabin dengan al ruh, dan ruh dengan karya kreatif primordial Tuhan. Semua bergerak dinamis dalam pola dasar yang selaras dan seimbang (Nasr, 1993: 57).

Masjid sebagai bentuk seni arsitektur suci Islam juga memperlihatkan hal serupa. Kekosongan, kesederhanaan, dan kemiskinan bentuk serta pola menunjukkan status ontologis dunia sebagai yang papa dan miskin di hadapan Tuhan Yang Maha Kaya. Ihwal ruang-ruang yang sunyi merefleksikan kedamaian, sedangkan lengkungan dan kolom-kolom ruangan adalah ritme yang mengimbangi eksistensi kosmik yang menjelaskan fase-fase kehidupan manusia dan juga kosmos yang datang dari-Nya maupun yang kembali kepadaNya (Nasr, 1993: 58). 
Kedua, mengikuti prinsip kesatuan hidup individu dan masyarakat yang diatur oleh hukum Ilahi (al syariah). Masjid di sebuah kota Islam tradisional, misalnya, bukan hanya sebagai pusat kegiatan religius melainkan juga seluruh kehidupan masyarakat, baik kultural, sosial dan politik, juga pada tahap tertentu kegiatan ekonomi. Karena itu, secara organis masjid senantiasa berhubungan dengan pasar sebagai pusat ekonomi, istana sebagai pusat kekuasaan politik, sekolah sebagai pusat kegiatan intelektual, dan seterusnya. Siapa yang memperhatikan kota Islam tradisional pasti melihat kesatuan dan keterpaduan seperti itu. Di pusat kota pasti ada masjid, berdekatan dengan istana dan pasar (Nasr, 1993: 73).

\section{Sumber Seni Islam}

Seseorang tidak akan menyamakan sebuah masjid dengan gereja, meskipun bahan bangunan masjid tersebut diambil dari gereja, misalnya. Artinya, cikal bakal seni Islam dan kekuatan-kekuatan serta prinsip-prinsip yang mendasarinya tidak mungkin digali dari kondisi sosio-politik yang mengiringinya, tetapi harus dihubungkan dengan pandangan dunia (world view) Islam sendiri. Sumber seni Islam harus dicari di dalam dan dikaitkan dengan realitas-realitas batin (haqaiq) al Quran yang merupakan realitas-realitas dasar kosmos dan realitas spiritual substansi nabawi yang mengalirkan 'berkah muhammadiyah' (al barakah al muhammadiyah). Aspek-aspek batin dan berkah Nabi inilah yang merupakan sumber seni Islam, yang tanpa keduanya tidak akan muncul seni Islam. Al Quran memberikan doktrin ke-Esaan, sedangkan Nabi memberikan manifestasi ke-Esaan ini dalam keberagaman dan kesaksian dalam ciptaan-Nya. Berkah Muhammadiyah memberikan daya kreativitas yang memungkinkan seseorang menciptakan seni Islam. Kenyataannya, menurut Nasr, para maestro seni Islam senantiasa memperlihatkan rasa cinta dan kesetiaan yang istimewa kepada Nabi dan keluarganya (Nasr, 1993: 17).

Selain itu, seni Islam juga berdasarkan atas hikmah, yakni pengetahuan yang diilhami oleh nilai-nilai spiritual. Seni Islam mewujudkan realitas-realitas yang ada dalam "perbendaharaan ghaib" (khazain al ghaib) lewat bantuan ilmu pengetahuan tentang dunia batin (hikmah) (Nasr, 1993: 19). Hal ini bisa dilihat, antara lain, pada bangunan masjid Syah di Isfahan, misalnya, atau arsitektur masjid lainnya yang dibangun dengan pola geometri dan arabeska (kaligrafi tradisional) yang luar biasa, atau pada melodi-melodi musik Arab tradisional yang memberikan alunan musik yang sangat menawan, yang jika direnungkan secara mendalam pasti akan sampai pada sebuah kesimpulan 
bahwa semua itu digali dari keindahan dunia kasat mata (Nasr, 1993: 50-74). Dengan demikian, karakter intelektual dari seni Islam tidak bisa dianggap sebagai hasil dari semacam rasionalisasi, melainkan dari suatu penglihatan intelektual terhadap pola-pola dasar dari dunia terestrial. Seni Islam juga tidak meniru bentuk-bentuk lahir alam, tetapi memantulkan prinsip-prinsipnya, sehingga ia bukan empirisme, tetapi sebuah scientia sacra yang hanya bisa diraih berdasarkan cara-cara tertentu. Kenyataannya, di manapun kehidupan intelektual dan spiritual Islam mencapai puncak, kreativitas seni Islam juga mencapai kesempurnaan. Sebaliknya, ketika kehidupan spiritual Islam mengalami keruntuhan, kualitas seni Islam juga mengalami kemunduran.

Seni Islam bukan sekadar karena ia diciptakan oleh seorang muslim, tetapi lebih karena didasari oleh wahyu Ilahi. Seni Islam adalah buah dari spiritualitas Islam, merupakan hasil dari pengejewantahan ke-Esaan pada bidang keanekaragaman. Ia merefleksikan kandungan prinsip ke-Esaan Ilahi, kebergantungan seluruh keanekaragaman kepada Yang Esa, kesementaraan dunia dan kualitas-kualitas positif dari eksistensi kosmos. Meski demikian, walaupun seni Islam diilhami oleh spiritualitas Islam secara langsung, wujudnya tetap saja dibentuk oleh karakter-karakter sosial budaya yang meliputinya. Hanya saja, karakter-karakter tersebut tidak sampai mengurangi kebenaran dan kandungan batin dan dimensi spiritual Islam yang menjadi sumber seni Islam (Nasr, 1993: 15).

\section{Fungsi Seni Islam}

Tidak berbeda dengan seni-seni lain yang mengandung banyak fungsi (Gie, 1996: 47-52), seni Islam juga mengandung fungsi-fungsi khusus. Seni Islam setidaknya mengandung empat pesan atau fungsi spiritual. Pertama, mengalirkan berkah sebagai akibat hubungan batinnya dengan dimensi spiritual Islam. Tidak bisa diingkari, seorang muslim yang paling modern sekalipun akan mengalami rasa kedamaian dan kegembiraan dalam lubuk hatinya, semacam 'ketenangan' psikologis, ketika memandang kaligrafi, duduk di atas karpet tradisional, mendengarkan dengan khusyuk bacaan tilawah al Quran, atau beribadah di salah satu karya besar arsitektur Islam (Nasr, 1993: 214).

Kedua, mengingatkan kehadiran Tuhan di mana pun manusia berada. Bagi seseorang yang senantiasa ingat kepada Tuhan, seni Islam selalu menjadi pendorong yang sangat bernilai bagi kehidupan spiritualnya dan sarana untuk merenungkan realitas Tuhan (al haqaiq). Bahkan, seni Islam yang pada dasarnya dilandasi wahyu Ilahi adalah penuntun manusia untuk masuk ke ruang batin 
wahyu Ilahi, menjadi tangga bagi pendakian jiwa untuk menuju pada Yang Tak Terhingga, dan bertindak sebagai sarana untuk mencapai Yang Maha Benar (al Haqq) lagi Maha Mulia (al Jalal) dan Maha Indah (al Jamal), sumber segala seni dan keindahan (Nasr, 1993: 17-18).

Kenyataan tersebut terjadi dalam semua bentuk seni Islam, seni kaligrafi misalnya. Kaligrafi yang merupakan seni perangkaian titik-titik dan garis-garis pada pelbagai bentuk dan irama yang tiada habisnya merangsang ingatan akan tindak primordial dari pena Tuhan. Ia merupakan refleksi duniawi atas firman Tuhan yang ada di Lauh Mahfuzh, yang menyuarakan sekaligus menggambarkan tanggapan jiwa manusia terhadap pesan Ilahi dan merupakan visualisasi atas realitas-realitas spiritual yang terkandung dalam wahyu Islam (Nasr, 1993: 27-29). Begitu pula dalam seni liturgi, tilawah al Quran, mengingatkan manusia akan keagungan Tuhan. Hal senada juga terjadi dalam syair-syair, musik, dan karya-karya sastra lainnya yang lahir dari model teks suci al Quran. Keselarasan bait-bait syair dan irama musik menghubungkan diri dengan keselarasan dan ritme universal kosmik (Nasr, 1993: 170).

Ketiga, menjadi kriteria untuk menentukan apakah sebuah gerakan sosial, kultural, dan bahkan politik benar-benar otentik Islami, atau hanya menggunakan simbol Islam sebagai slogan untuk mencapai tujuan tertentu. Sepanjang sejarah dan dengan kedalaman serta keluasan manifestasi otentiknya, mulai dari arsitektur sampai seni busana, seni Islam senantiasa menekankan keindahan dan ketakterpisahan darinya (Nasr, 1993: 218). Apakah mereka yang mengklaim berbicara atas nama Islam juga telah menciptakan bentuk-bentuk keindahan dan kedamaian? Apakah ada kualitas ketenangan, keselarasan, kedamaian, dan keseimbangan yang menjadi ciri khas Islam maupun manifestasi artistik dan kulturalnya, dalam sikap dan perilaku gerakan-gerakan dan organisasi Islam tersebut?

Keempat, sebagai kriteria untuk menentukan tingkat hubungan intelektual dan religius masyarakat muslim. Saat ini banyak tokoh berbicara tentang islamisasi ilmu, pendidikan, sistem ekonomi maupun sistem masyarakat Islam sendiri, di samping banyak yang melakukan berbagai usaha konkret untuk mencapai tujuan tersebut. Semua itu bukan usaha yang mudah dan pasti menghadapi kendala dan tantangan yang berat. Apakah mereka yang melakukan usaha-usaha tersebut menyadari bentuk keislaman di luar ketentuan syari`ah yang bersifat eksoterik? Seni Islam dalam pengertian universalnya dapat dijadikan kriteria untuk menilai 
sifat proses pencapaian tersebut beserta hasil-hasilnya, karena tidak ada yang autentik Islam tanpa memiliki kualitas yang lahir dari spiritual dan menjelmakan dirinya di sepanjang sejarah seni tradisional Islam, mulai dari tembikar hingga sastra dan musik. Artinya, tingkat keberhasilan yang dicapai yang bisa diukur lewat data-data empiris berkaitan dan sekaligus menunjukkan tingkat kualitas spiritual yang menyertainya.

\section{Simpulan}

Karya seni Islam, bagi Nasr bukan sekadar karena ia lahir dari seorang muslim melainkan karena ia digali dan mengekspresikan dimensi-dimensi spiritual Islam dan merefleksikan prinsip-prinsip tauhid. Inilah ciri khas pemikiran Nasr yang perennial. Gagasan ini hampir sama dengan teori seni dan keindahan Iqbal. Bedanya, seni Nasr merupakan ekspresi dimensi spiritual, sedangkan seni Iqbal adalah ekspresi kreatif ego. Namun, terlepas dari perbedaan dan corak pemikirannya, cara pandang Nasr ini adalah sesuatu yang sangat positif, bisa digunakan sebagai solusi alternatif atas dampak negatif modernitas yang ternyata justru menjauhkan manusia dari spiritualitas (Nasr, 1983: 32-33).

Meski demikian, konsep seni Nasr juga bukan sekadar ekspresi spiritual, melainkan harus mampu membawa fungsi-fungsi tertentu. Paling tidak ada empat fungsi yang harus diemban oleh seni Islam. Karena itu, karya seni tidak bersifat otonom, mandiri, tetapi harus berkaitan norma dan tujuan tertentu, sehingga tidak ada istilah seni untuk seni atau l'art pour l'art. Dalam kajian filsafat, konsep seni seperti ini diklasifikasikan dalam aliran seni fungsional: yaitu bahwa seni harus mempunyai fungsi dan tujuan-tujuan tertentu yang umumnya berkaitan dengan moral.

Namun, hal itu bukan berarti tanpa persoalan. Seperti pernah ditulis Faisal Ismael, jika seni dikaitkan atau bahkan dibatasi oleh agama, maka akan menyebabkan beberapa hal. Pertama, adanya keterikatan bentuk dan isi dari seni itu sendiri. Kedua, adanya ketegangan antara nilai seni yang longgar dengan nilai agama yang ketat. Ketiga, terbatasnya ruang gerak seni karena dipakai sebagai bagian dari praktik keagamaan. Keempat, terganggunya kebebasan kreativitas karena adanya norma-norma agama yang mengatur (Ismael, 1996: 65-66). Berdasarkan hal ini, tidakkah pemikiran Nasr justru akan menyebabkan seni Islam sulit berkembang? 


\section{Daftar Pustaka}

Azzam, Abd Wahhab. 1985. Filsafat dan Puisi Iqbal. Bandung: Pustaka.

Dahlan, Abd Aziz (Ed.). 1996. Suplemen Ensiklopedia Islam. Edisi II. Jakarta: Ichtiar Baru Van Haouve.

Gie, The Liang. 1996. Filsafat Seni. Yogyakarta: Pubib.

Ismael, Faisal. 1996. Paradigma Kebudayaan Islam. Yogyakarta: Titian Ilahi Press.

Mudhaffir, Ali. 1988. Kamus Teori $\mathcal{G}$ Aliran dalam Filsafat. Yogyakarta: Liberty.

Nasr, Husein. 1968. The Encounter of Man and Nature. London: George Allend \& Unwin Ltd.

Nasr, Husein. 1972. Sufi Essays. New York: University of New York Press.

Nasr, Husein. 1983. Islam E Nestapa Manusia Modern. Terjemahan oleh Anas Mahyudi. Bandung: Pustaka.

Nasr, Husein. 1986. Sains dan Peradaban dalam Islam. Terjemahan oleh J. Mahyudin. Bandung: Pustaka.

Nasr, Husein. 1993. Spiritualitas $\mathcal{E}$ Seni Islam. Terjemahan oleh Setejo. Bandung: Mizan.

Qadir, CA. 1997. Filsafat dan Ilmu Pengetahuan dalam Islam. Terjemahan oleh Mulyadi Kartanegara. Jakarta: Pustaka Jaya.

Smith, Jane I. 1995. Sayyid Husein Nasr dalam John L. Esposito (Ed.). The Oxford Encyclopedia of the Modern Islamic World. New York: Oxford University Press.

Syarif. 1993. Iqbal tentang Tuhan dan Keindahan. Bandung: Mizan. 